\title{
Marcas em cena
}

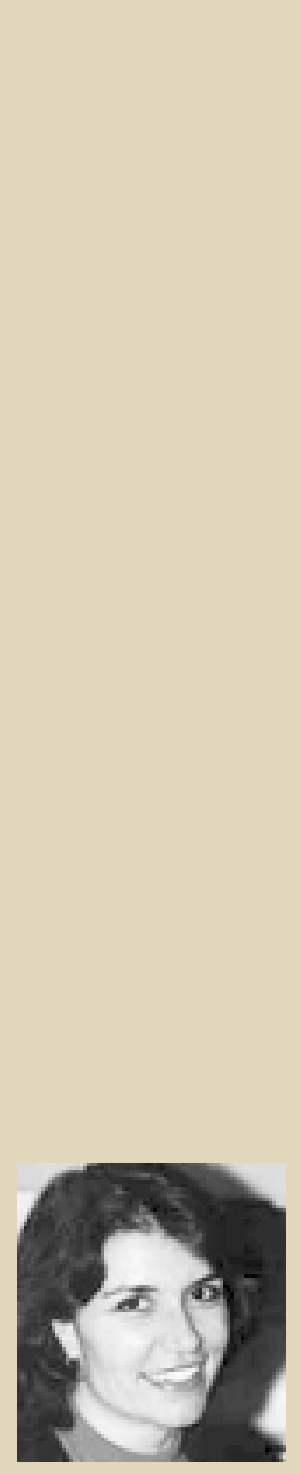

Inês Pereira FGV-EAESP

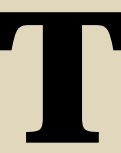

em se tornado cada vez mais comum o aparecimento de marcas de produtos em filmes de cinema ou de TV em troca de dinheiro, promoção ou outro benefício concedido pelo anunciante. Essa prática é denominada de product placement (PP). Sua origem não é recente. Em 1948, no filme americano Mildred Pierce, a personagem interpretada pela atriz Joan Crawford já aparecia bebendo uísque Jack Daniel's. Dois anos mais tarde, quatro astronautas do filme $D$ estination M oon decolaram em direção à lua bebendo Coca-Cola e vestindo jeans Lee.

Uma das vantagens do PP é que ele pode custar menos que a propaganda e não exigir investimentos em produção de filmes. Outra vantagem é que contorna a questão da decrescente efetividade dos anúncios tradicionais, ocasionada pelo zapping, pela expansão da TV a cabo e pelo advento de tecnologias como 0 digital video recorder (DVR), o gravador digital de tel evisão. 0 DVR grava até 80 horas de programação, de acordo com a seleção de telespectador. Tem ainda uma função que permite avançar em intervalos de 30 segundos. Com ela, o telespectador pode saltar os anúncios dos interval os comerciais com grande facilidade. Assim, à medida que o uso dessa tecnologia se tornar comum, o interesse dos anunciantes pelo PP deve aumentar.

0 PP pode ser mais persuasivo que 0 anúncio tradicional, pois integra a marca ao enredo, demonstrando o produto em seu uso natural, sem causar ruptura na linearidade da história. Porém, é preciso haver equilíbrio entre 0 enredo e a propaganda, de tal forma que a presença do PP não seja percebida como intrusiva, despertando uma reação negativa da audiência.

No Brasil, o PP échamado demerchandising. $\mathrm{Na}$ TV Globo, por exemplo, existe uma área comercial responsável por comercializá-lo em suas novelas e minisséries. Com o script em mãos, e em conjunto com a área de criação e roteiristas, essa área analisa as possibilidades de inserção de marcas no momento da produção. Após a assinatura do contrato, a inserção é produzida e vai ao ar dentro de um prazo de quinze dias.

Tal prática se configura em tendência geral de mercado. Considerando-se a correção monetária dos valores pelo IGP-M, os investimentos em PP na TV Globo apresentaram, entre 2001 e 2002, um crescimento real de $12 \%$ e, entre 2002 e 2003 , de $20 \%$. 0 primeiro trimestre de 2004, quando comparado ao mesmo período do ano anterior, apresentou crescimento de $83 \%$. Essas cifras mostram que há uma clara tendência de crescimento do PP no mercado brasileiro, crescimento esse que deve ser levado em conta pelos anunciantes, publicitários e pesquisadores.

\section{Colaborou Daniel Fonseca FG V-EAESP}

